\title{
Goal Engagement During the School- Work Transition: Beneficial for All, Particularly for Girls
}

\author{
Claudia M. Haase \\ University of Jena, Germany \\ Jutta Heckhausen \\ University of California, Irvine \\ Olaf Köller \\ Humboldt University of Berlin, Germany
}

\begin{abstract}
The school-to-work transition presents a substantial regulatory challenge for youth in modern societies. Based on the action-phase model of developmental regulation, we investigated the effects of goal engagement on transition outcomes in a high-density longitudinal study of noncollege-bound German adolescents $(N=362)$. Career-related goal engagement was important for attaining a desired career goal (i.e., apprenticeship) for girls who generally faced unfavorable employment opportunities. For boys, goal engagement did not predict the attainment of an apprenticeship. Goal engagement was nonetheless beneficial for well-being, predicting positive affect for both girls and boys. This effect was not mediated by attainment of an apprenticeship. The findings elucidate the role of goal engagement under structural and temporal constraints and suggest possible avenues for intervention.
\end{abstract}

The school-to-work transition is a central milestone in the transition from adolescence to adulthood in many societies (e.g., Blustein, 1999; Lent \&

Requests for reprints should be sent to Claudia M. Haase, Center for Applied Developmental Science, University of Jena, Am Steiger 3/1, D-07743 Jena, Germany. E-mail: claudia. m.haase@uni-jena.de 
Worthington, 1999; Nurmi \& Salmela-Aro, 2002; Schulenberg, Maggs, \& Hurrelmann, 1997; Shanahan, Mortimer \& Krüger, 2002; Vondracek, Lerner, \& Schulenberg, 1986). This is reflected not only in normative developmental tasks that ascribe significant importance to career and work (Vondracek \& Porfeli, 2003) but also in the central role of work in identity and personal goals of adolescents (Kalakoski \& Nurmi, 1998). The transition from school to work holds chances for upward as well as risks for downward social mobility. Thus, adaptive strategies for a successful navigation of the school-to-work transition often are decisive for longterm development (Heckhausen, 2002).

In recent years, it has become increasingly difficult for adolescents to navigate the school-to-work transition. Labor markets have become more deregulated, which is reflected in increasing job uncertainty, a proliferation of underemployment, increasing unemployment, and increasing discontinuities in individual career trajectories (Organization for Economic Co-operation and Development, 2003). According to a large 14-nation study (Blossfeld, Klijzing, Mills, \& Kurz, 2005), particularly adolescents-identified as the "losers in a globalizing world" by the authors-face work-related uncertainty in many societies.

This is particularly true for the "forgotten half" (e.g., Halpern, 1998). In some countries, such as Germany, non-college-bound youth traditionally have received institutional support (Hamilton, 1990), whereas in other countries, including the United States, the school-to-work transition has not been institutionally structured. However, also in Germany, economic change has increasingly destabilized the transition from school to employment for these adolescents (Heinz, 2002). Empirical evidence shows that individual regulation gains increasing importance when socioinstitutional regulation decreases (e.g., Heckhausen, 1999; Silbereisen, Best, \& Haase, 2007; Wrosch \& Freund, 2001; see also Beck, 1986; Sennett, 1998).

How individuals "produce" (Lerner \& Busch-Rossnagel, 1981) their own development has attracted considerable interest in developmental psychology (e.g., Baltes \& Baltes, 1990; Brandtstädter \& Rothermund, 2002; Bühler, 1933; Heckhausen, 1999; Nurmi \& Salmela-Aro, 2006) and life-course sociology (e.g., Clausen, 1991; Elder, 1998; Emirbayer \& Mische, 1998). Developmental goals - which can be conceived as internalized developmental tasks (Heckhausen, 1999)—are particularly interesting in this regard. The importance of individual goals for general psychological adaptation is well documented (e.g., Austin \& Vancouver, 1996; Little, Salmelo-Aro, \& Phillips, 2006). We suggest that on-time engagement with career-related developmental goals should be crucial for a productive mastery of the transition from school to work. 
School-to-work transition studies show that individual goals and motivational processes have positive effects on objective career success, including self-efficacy (Pinquart, Juang, \& Silbereisen, 2003), prioritizing work-related goals (Nurmi, Salmela-Aro, \& Koivisto, 2002), expecting success and avoiding internal attributions after failure (Määttä, Nurmi, \& Majava, 2002), engaging in job-search behavior (Pinquart et al., 2003), and career exploration (Kracke, 2002). A meta-analysis by Kanfer, Wanberg, and Kantrowitz (2001), including studies on initial transitions in the workplace, reemployment following nonwork or layoff, and job-to-job transitions, provides evidence for the positive effect of active and engaged job-search behavior on later employment status across a wide range of career-related transitions (see also Saks \& Ashforth, 1999; Wanberg, Glomb, Song, \& Sorensen, 2005). Finally, a large body of findings from the achievement domain shows that motivational factors, namely success expectancies, task values, and achievement goals, consistently emerge as predictors of goal attainment as measured by academic achievement (e.g., Eccles \& Wigfield, 2002; Linnenbrink \& Pintrich, 2002).

Furthermore, individual goals and motivation are crucial for subjective well-being (e.g., Emmons, 1986). Findings show that personal goals that reflect age-related developmental tasks or current life challenges foster well-being in various life-span transitions and developmental contexts (Salmela-Aro \& Nurmi, 1997; Salmela-Aro, Nurmi, Saisto, \& Halmesmäki, 2001; Wiese, Freund, \& Baltes, 2002) including the school-to-work transition (e.g., Määttä et al., 2002). For example, Nurmi and Salmela-Aro (2002) showed that personal goals that reflect on-time developmental tasks-e.g., find a job after graduation-are beneficial for post-transition well-being.

In sum, empirical evidence suggests that career-related goal engagement is important for both career goal attainment as well as subjective well-being during the school-to-work transition. Whereas most school-towork transition studies-not only in developmental psychology but also in adjunct fields (e.g., Lent \& Worthington, 1999)—have focused on career goal selection and decision-making, not much is known about how individuals put their goals forth into action (see Lewin, 1926, for the motivation-volition distinction). In this paper, we address this point drawing from the action-phase model of developmental regulation.

\section{THE ACTION-PHASE MODEL OF DEVELOPMENTAL REGULATION}

The action-phase model of developmental regulation (Heckhausen, 1999) proposes a theoretical framework for how individuals pursue goals during 


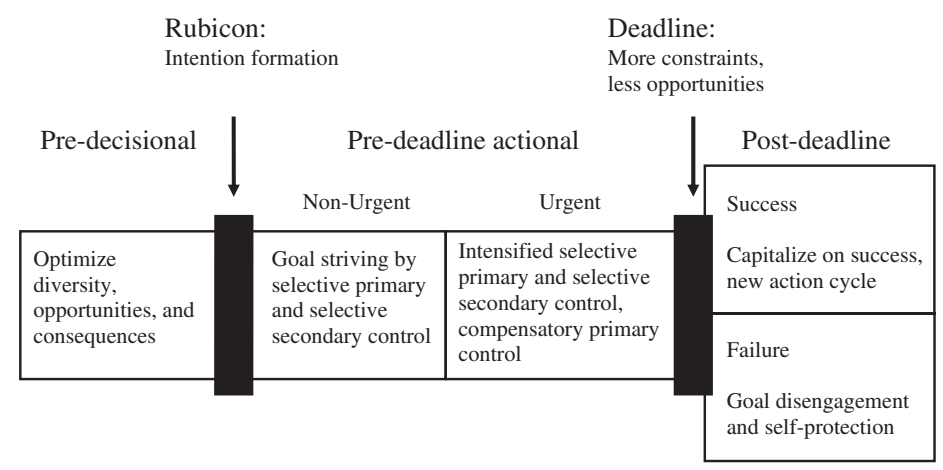

FIGURE 1 Action-phase model of developmental regulation.

Note. Adapted from Developmental Regulation in Adulthood: Age-Normative and Sociostructural Constraints as Adaptive Challenges (p. 114), by Heckhausen, 1999, New York: Cambridge University Press. Copyright 1999 by Cambridge University Press. Adapted with permission of the publisher.

life phases when contextual opportunities for goal attainment undergo change. The model constitutes a theoretical extension of the Rubicon model (see Heckhausen \& Heckhausen, 2006) and is based on the life-span theory of control, which has been proposed as a unifying framework for social scientists to study life-span development (Heckhausen \& Schulz, 1995; Schulz \& Heckhausen, 1996) across a wide range of domains, including career development (Shanahan \& Porfeli, 2002). The theory assumes that individuals combine two types of control strategies in their attempts to shape their own development: primary control, aimed at changing the environment, and secondary control, directed at the self (Rothbaum, Weisz, \& Snyder, 1982).

The action-phase model of developmental regulation addresses how individuals use primary and secondary control strategies in adaptive ways as they move through the different action phases of choosing, striving for, and eventually disengaging from a developmental goal (see Figure 1). Once individuals have committed to a goal—crossed the decisional " $\mathrm{Ru}$ bicon"- they enter the goal engagement phase. During this goal-striving phase, individuals' primary and secondary control should be selectively focused on the chosen goal. Selective primary control strategies refer to the investment of behavioral resources, such as effort and energy during goal striving, whereas secondary control strategies comprise volitional strategies, such as resisting distractions by other competing goals. When a developmental deadline-marking a shift from better to worse opportunities for goal attainment-approaches, goal engagement becomes urgent. 
At that point, investing resources and staying focused are crucial for the individual who strives for a developmental goal. Compensatory primary control strategies (e.g., getting someone's help) might also be activated. Finally, when a point is reached where the opportunities of goal attainment have all but disappeared, the developmental deadline is crossed, and the individual is better off disengaging from the now futile goal. In contrast, when the individual has reached her goal, she experiences positive affect, can capitalize on her success, and start to choose and pursue other goals (see Havighurst, 1976). Note that the model conceptualizes well-being not as an ultimate goal but rather as an important but often temporary (Diener, Lucas, \& Scollon, 2006) byproduct of goal progress and attainment.

The action-phase model has been applied to several developmental tasks and transitions and has yielded consistent findings (for an overview, see Heckhausen \& Heckhausen, 2006). Studies demonstrate that adolescents and adults at different ages anticipate and take into account developmental deadlines when planning investments in diverse areas of development, such as building a family (Heckhausen, Wrosch, \& Fleeson, 2001; Wrosch \& Heckhausen, 1999), coping with health problems and financial difficulties (Wrosch, Heckhausen, \& Lachman, 2000), and navigating the school-to-work transition (Heckhausen \& Tomasik, 2002; Nagy, Köller, \& Heckhausen, 2005; Poulin \& Heckhausen, 2007). In all these different domains, individuals activate control strategies in congruence with their particular goal attainment opportunities (i.e., engage when opportunities are good, disengage when opportunities are bad). Moreover, and even more important, these studies demonstrate that those individuals who show the most phase-congruent engagement and disengagement pattern also obtain the best developmental outcomes.

The action-phase model makes specific predictions about how individual and context co-jointly regulate development (Heckhausen, 1999; Heckhausen \& Schulz, 1999). Individual goal engagement becomes more important for goal attainment when little support and scaffolding is provided by the context. Context opportunities can vary across time-as evident in the waxing and waning opportunity structure around a developmental deadline- but they also vary along stable, dividing lines in the social structure of a society (Bourdieu \& Passeron, 1990).

Thus, like other models proposed in life-span developmental psychology and life-course sociology (e.g., Bronfenbrenner, 1979; Elder, 1998; Evans, 2007; Heinz, 2002; Lerner \& Walls, 1999), the action-phase model explicitly addresses the contextual embeddedness of individual agency. The model further shares similarities with other coping, regulation, and motivation theories (e.g., Lazarus \& Folkman, 1984), particularly with 
developmental regulation theories (Baltes \& Baltes, 1990; Brandtstädter \& Rothermund, 2002; Nurmi \& Salmela-Aro, 2006), but it also departs from them in notable ways (for a detailed discussion, see Heckhausen \& Heckhausen, 2006; Poulin, Haase, \& Heckhausen, 2005). Importantly, the model addresses goal engagement-and disengagement-under stable as well as changing life-course structured opportunities and constraints. The model thus seems particularly suited to analyze goal engagement during deadline-bound life-span transitions.

\section{THE SCHOOL-TO-WORK TRANSITION}

The school-to-work transition is bound to more or less tight deadlines in different countries around the globe. Thus, timing is decisive, and individuals who experience a delayed transition into work life show higher levels of depression (Nurmi \& Salmela-Aro, 2002), lower well-being (Schulenberg, Bryant, \& O'Malley, 2004), and a heightened risk of substance misuse (Dooley \& Prause, 2004). In some countries, the transition shift from better to worse opportunities-the deadline-is less pronounced due to higher flexibility of educational and vocational training institutions and greater permeability of career tracks. In Germany, however, this shift is perhaps most discrete and its consequences most influential (Heckhausen, 2002).

In Germany, as early as in fourth grade or, at the latest, after the sixth grade, children are segregated into three different school tracks (Schnabel, Alfed, Eccles, Köller, \& Baumert, 2002). Only the highest school track qualifies for college entry. Adolescents from the two lower school tracksthe present study addressed youth in the middle school track-are not eligible for college. Typically, these adolescents enter a so-called apprenticeship system after school graduation where they obtain vocational certificates needed for skilled employment (e.g., Heinz, 2002). Apprenticeship positions are offered and paid for by private companies and businesses in more than 300 occupations, which differ in social prestige, income, and gender typicality (Heckhausen \& Tomasik, 2002; Heinz, 2000). Apprenticeship programs typically start in September and last for three years. During this time, adolescents learn and work in a company or business and also receive vocational schooling. Although adolescents can, in principle, start an apprenticeship every year, their actual chances to attain a position shrink dramatically already two years after graduation (Blossfeld, 1990; Dietrich, 2004), which is why we conceive this transition as a developmental deadline (i.e., a discrete shift from better to worsebut not necessarily nil—opportunities). 
Non-college-bound German youth consider attaining an apprenticeship after graduation the "main thing" (Heinz, 2008). However, apprenticeship positions are increasingly in short supply and about $40 \%$ of students end up without an apprenticeship at the end of their senior year (cf. Heckhausen \& Tomasik, 2002; Heinz, 2002). Representative data show that German adolescents are aware of this competitive situation: They name "not getting an apprenticeship" as one of their most important fears (Jugendwerk der Deutschen Shell, 1997). Failure to enter the apprenticeship system indeed has considerable long-term consequences, including a heightened risk for underemployment and unemployment (e.g., Heinz, 2002), and, in turn, a delayed transition to adulthood (Reitzle \& Silbereisen, 2000). In contrast, adolescents who do attain an apprenticeship profit not only in terms of higher future income, they later also attain jobs that are more intrinsically rewarding (Hamilton \& Lempert, 1996). Some adolescents who do not attain an apprenticeship are diverted into state-run vocational schools and programs. However, their employment chances are clearly inferior (Dietrich, 2004).

Educational attainment, socioeconomic background, and gender constitute cornerstones of social inequality in many societies (Bourdieu, 2001; Bourdieu \& Passeron, 1990; Schoon et al., 2002). These factors also affect school-to-work transition success (e.g., Bynner, 1998; Gaskell, 1992; Hamilton \& Lempert, 1996, Lehmann, 2004). In Germany, the situation is particularly difficult for girls: Only $<30 \%$ of all apprenticeship positions are offered in female-typed professions (Granato \& Schittenhelm, 2004). As career choice is "gendered" in Germany (Christmas-Best \& Schmitt-Rodermund, 2001) as in other countries (e.g., Eccles, 1994; Watt \& Eccles, 2008), girls are particularly at risk for labor market exclusion during the transition from school to work in Germany (Heinz, 2000).

\section{THE PRESENT STUDY}

In the present study, we examined adolescent goal engagement during the school-to-work transition. The specific developmental context-the German apprenticeship system-allowed us to investigate goal engagement in high-versus low-opportunity situations and hence to elucidate general phenomena of goal engagement in more or less challenging transition contexts. We utilized data from a multi-year longitudinal school-to-work transition study. Previous analyses utilizing this data set have focused on how adolescents adjust their career aspirations to their school achievement (Heckhausen \& Tomasik, 2002), how they regulate their application behavior (Nagy et al., 2005), and how critical life events affect their 
career-related goal engagement (Poulin \& Heckhausen, 2007) before school graduation. The present study was the first to examine post-graduation outcomes and goal engagement as a pre-graduation antecedent.

\section{Hypotheses}

Based on the action-phase model of developmental regulation, we investigated the effects of career-related goal engagement indicated by effort investment and volitional focus on career goal (i.e., apprenticeship) attainment and positive affect. (1) We expected goal engagement before graduation to predict apprenticeship attainment after graduation over and above the effects of school achievement, parental education, and gender. We further investigated whether these factors moderated the effect of goal engagement. We expected individual goal engagement to be more important for individuals facing less favorable opportunities, namely females and individuals with lower school achievement and parental education. Moreover, we expected goal engagement to become more important under increasing temporal urgency, that is, the closer adolescents were approaching graduation.

(2) We expected goal engagement before graduation to predict positive affect after graduation controlling for baseline positive affect. Again, we expected goal engagement to predict positive affect more strongly with increasing temporal urgency. Finally, we hypothesized apprenticeship attainment to mediate the effect of goal engagement on positive affect. The action-phase model does not make predictions of how disadvantages due to structural constraints moderate the effect of goal engagement on positive affect, which is conceived as a byproduct of goal attainment. However, as we conceptualized goal attainment as a mediator, we also investigated the main and interaction effects of achievement, parental education, and gender.

\section{METHOD}

\section{Participants}

We analyzed data from a study on developmental regulation during the transition from school to work or to higher education. Three cohorts of students from four middle-tier schools (i.e., Realschule) in Berlin were followed in a longitudinal study. Schools were selected based on census data (Senatsverwaltung für Gesundheit und Soziales, 1990). Two schools were located in middle-class neighborhoods and two schools were situ- 
ated in working-class neighborhoods. One school from each SES group was drawn from East and West Berlin, respectively.

At the beginning of 10th grade (i.e., the senior school year), 631 students participated in the study. Attrition during senior year was low due to obligatory school attendance (see Heckhausen \& Tomasik, 2002; Poulin \& Heckhausen, 2007). Retention rates were $95.6 \%$ at wave $4,93.2 \%$ at wave 5 , $92.9 \%$ at wave 6 , and $86.8 \%$ at wave 7 . Attrition after graduation was considerably higher ( $n$ retained $=447,70.8 \%$ ). Selectivity analyses indicated that attrition after graduation was nonselective with regard to sociodemographic variables and goal engagement. In this paper we were only interested in developmental trajectories of adolescents who were potentially eligible to enter the apprenticeship system after graduation $(n=362,81.0 \%)$. A small number of middle-tier students enter higher education after 10th grade in order to obtain 3 more years of schooling. We excluded these students $(n=85,19.0 \%)$ from our analyses.

The final sample comprised 362 adolescents ( $n=192,53.0 \%$ females). At the beginning of their senior year, adolescents were 15.99 years $(M)$ old $(S D=.62)$. On average, their parents had attained about 11 years of education $(M=11.12, S D=1.71)$. Most $(85.1 \%)$ adolescents had German citizenship; $9.1 \%$ reported other nationalities.

\section{Measures}

Goal engagement. Goal engagement was measured by the Optimization in Primary and Secondary (OPS) Control scale, which has shown adequate measurement properties and validity in previous studies (Heckhausen et al., 2001; Heckhausen, Schulz, \& Wrosch, 1998; Wrosch \& Heckhausen, 1999). In the present study, the scale was tailored to the career domain and showed adequate reliability and validity (Heckhausen \& Tomasik, 2002; Poulin \& Heckhausen, 2007). Specifically, goal engagement was measured by selective primary and selective secondary control strategies. Four items reflected investment of behavioral effort with regard to goal engagement (example item: "I invest all my energy in order to get a suitable apprenticeship") and four items reflected volitional strategies with regard to goal engagement (example item: "When I am thinking about my career I keep saying to myself that I will surely be successful."). A five-point scale was used, with answers ranging from strongly disagree (1) to strongly agree (5). The complete scale can be found in the appendix. Internal consistency was high at all waves (wave 4: $\alpha=.85$, wave 5: $\alpha=.84$, wave 6: $\alpha=.85$, wave $7: \alpha=.83$ ). 
In terms of scale validity, our measure of career-related goal engagement was associated with the use of specific behavioral strategies. We found that adolescents with higher goal engagement were more likely to study journals on apprenticeship seeking $(r=.21, p<.001)$, talk to their parents about what to do after graduation $(r=.15, p<.01)$, and were more willing to relocate in order to improve their apprenticeship chances $(r=.22, p<.001)$. Goal engagement also predicted how many applications adolescents sent out. Following Nagy et al. (2005), the longitudinal change in applications sent was modeled using latent growth curve modeling. We found that adolescents with higher initial goal engagement showed a steeper linear increase in the number of applications they sent out $(\beta=.24$, $p<.05)$.

Apprenticeship. After graduation, students indicated whether they had attained an apprenticeship position (1) or not (0).

Positive affect. Positive affect was assessed using the positive affect subscale from the Positive and Negative Affect Schedule (PANAS; Watson, Clark, \& Tellegen, 1998). The subscale included 10 items measuring general positive affect during the last month (e.g., excited, interested, enthusiastic). Positive affect was measured after graduation $(\alpha=.82)$. Analyses were controlled for baseline positive affect at wave $4(\alpha=.80)$, wave $5(\alpha=.79)$, wave $6(\alpha=.79)$, and wave $7(\alpha=.85)$, respectively.

Moderating factors. We included school achievement, gender, and parental education as moderators in our analyses. School achievement was indicated by students' grades in German, mathematics, English, and history, with higher scores reflecting better achievement $(\alpha=.70)$. Gender was coded as either male (0) or female (1). In order to indicate years of parental education we coded the highest educational level obtained by either mother or father (cf. Schnabel et al., 2002).

\section{Procedure}

The study used a dense longitudinal design with multiple measurement points before and after graduation. In Germany, middle-tier students graduate after 10th grade if they do not move on to higher education. Two waves of data collection were scheduled during the 9 th grade $(1,2)$, five were scheduled at two-month intervals during the 10 th grade $(3,4,5,6,7)$, and one was scheduled after graduation (8). In the present analyses, we analyzed data collected in the goal-striving phase before graduation, from 
waves $4,5,6$, and 7 . The outcome variables were measured at wave 8 , six months after graduation. In a previous study (Nagy et al., 2005), we had found that most students had not yet entered the goal-striving phase at wave 3 , which is why we started analyzing goal engagement at wave 4 .

Before the study parental consent was obtained for all study participants. Students filled out written questionnaires during regular classroom hours while teachers were absent. These sessions were led by trained personnel and lasted approximately 90 minutes. Participants received a small token (value $<\$ 1$ ) after completing the questionnaire. After graduation, surveys were mailed to the participants, who were compensated with DM 30 (about \$15) after they returned the questionnaire.

\section{RESULTS}

We conducted three sets of analyses. First, we examined intercorrelations between variables. Second, we analyzed longitudinal associations between goal engagement and apprenticeship attainment. Third, we investigated longitudinal relations between goal engagement and positive affect. In the latter two sets of analyses, we investigated school achievement, parental education, and gender as moderators of the effects of goal engagement variables following Cohen, Cohen, West, and Aiken (2003). We will describe the results for goal engagement measured at wave 4 in detail. Data from waves 5,6 , and 7 were used to examine whether goal engagement effects became stronger across time and will be discussed in more brevity.

Before our analyses we z-standardized all variables (Cohen et al., 2003). Missing data were replaced by means of the Expectation Maximum (EM) algorithm (Little \& Rubin, 1987) implemented in SYSTAT. The EM algorithm substitutes missing values for estimated values by maximizing the log-likelihood function of the data in an iterative process. Data were imputed by entering sociodemographic characteristics and other variables used in the present analyses as predictors with a convergence criterion of $p<.001$. All data analyses were conducted using imputed data. When analyses were repeated using the original data set without replacement of missing data the results did not change substantively.

\section{Intercorrelations of Variables}

First, we examined bivariate correlations between variables for the whole sample (Table 1, upper diagonal) and separately for boys and girls (Table 1, lower diagonal). Goal engagement showed substantial intercorrelations across time as did positive affect. Adolescents with higher goal engage- 


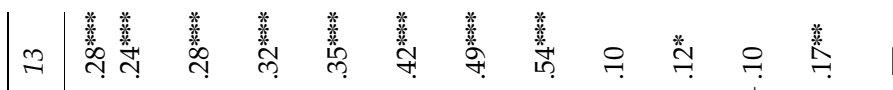

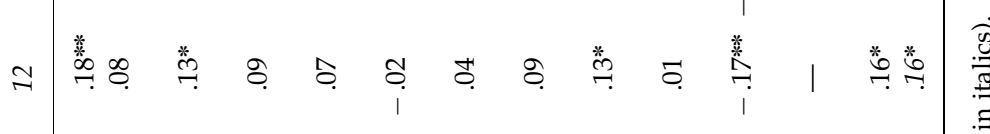

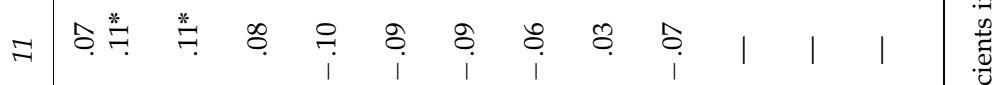

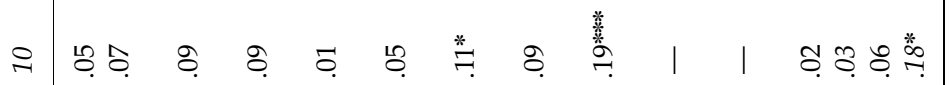

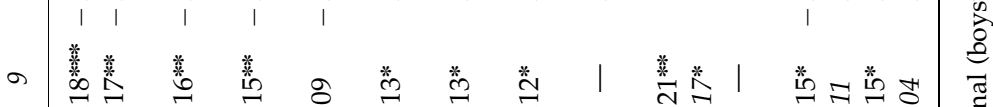

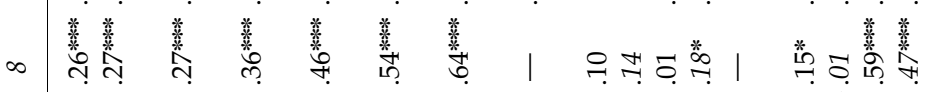

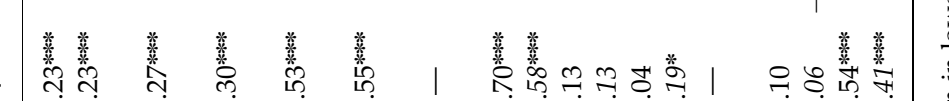

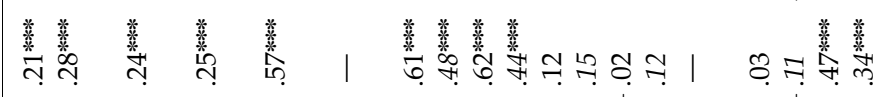

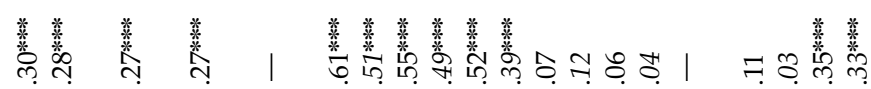

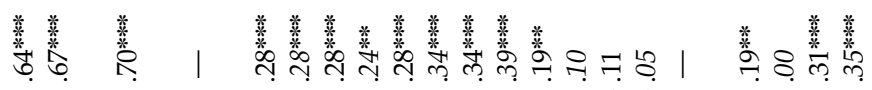

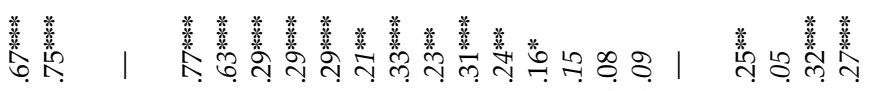

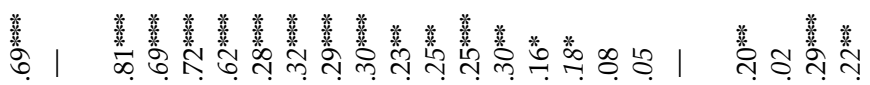

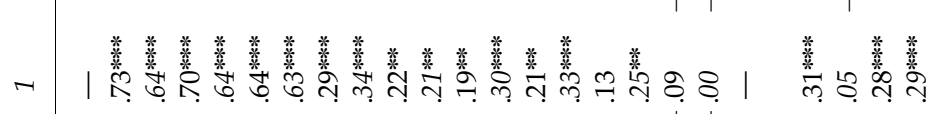

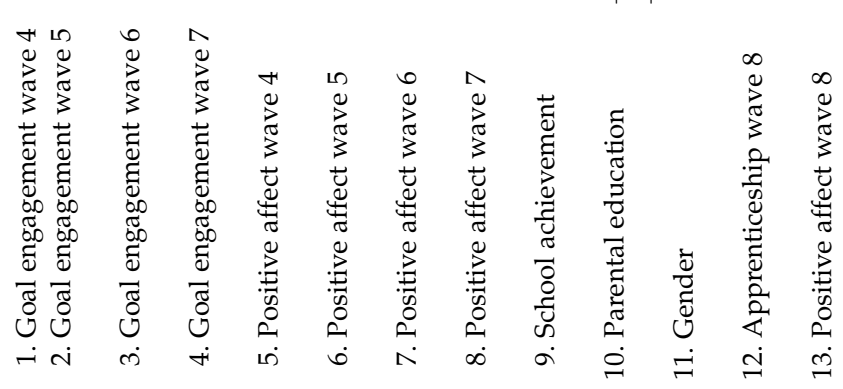

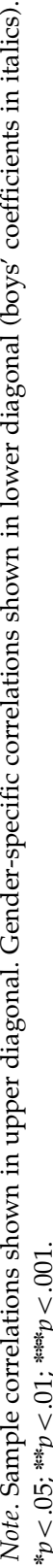


ment reported higher positive affect before and after graduation. Goal engagement was positively related to school achievement and did not correlate with parental education. Associations between goal engagement and gender were small and did not emerge at all waves. Adolescents with better school achievement had parents with higher education.

\section{Goal Engagement and Apprenticeship Attainment}

In the second set of analyses, we analyzed longitudinal associations between goal engagement and apprenticeship attainment. We first tested whether goal engagement before graduation predicted apprenticeship attainment after graduation over and above the effects of school achievement, parental education, and gender. As we found a significant engagement $\times$ gender interaction, we investigated the engagementapprenticeship link separately for girls and boys. Finally, we analyzed whether goal engagement effects on apprenticeship attainment became stronger across time separately for girls and boys.

Did goal engagement before predict apprenticeship attainment after graduation? Results from the hierarchical logistic regression analyses predicting apprenticeship attainment are depicted in Table 2. In the first step, school achievement, parental education, and gender were entered in the model. School achievement and gender predicted apprenticeship attainment whereas parental education did not. Goal engagement was included in the model in the second step and emerged as a predictor of apprenticeship attainment. In the third step, we tested whether gender,

TABLE 2

Predicting Apprenticeship Attainment After Graduation

\begin{tabular}{lccc}
\hline & Step 1 & Step 2 & Step 3 \\
\hline School achievement & $1.35^{*}$ & 1.26 & $1.28^{*}$ \\
Parental education & .95 & .97 & .97 \\
Gender & $.49^{* *}$ & $.46^{* *}$ & $.48^{* *}$ \\
Goal engagement & & $1.45^{* *}$ & 1.06 \\
School achievement $\times$ Goal engagement & & & 1.00 \\
Parental education $\times$ Goal engagement & & & .95 \\
Gender $\times$ Goal engagement & .06 & .10 & $1.80^{*}$ \\
Nagelkerke's $R^{2}$ & & .12 \\
\hline
\end{tabular}

Note. Goal engagement measured at wave 4 . Odds ratios $(\operatorname{Exp}(B))$ shown. $* p<.05 ; * * p<.01$. 
parental education, and school achievement moderated the effect of goal engagement on apprenticeship attainment. A significant gender $\times$ goal engagement interaction was found. In an additional analysis (not shown in Table 2), interactions between the three structural variables were tested. No significant effects were found.

Table 2 depicts the findings when analyzing goal engagement measured at wave 4 . All results remained stable across time analyzing goal engagement measured at waves 5,6 , and 7 , respectively. The gender $\times$ goal engagement interaction effect was found at wave $5(\operatorname{Exp}(B)=1.60, p<.05)$ and tended toward significance at waves $6(\operatorname{Exp}(B)=1.58, p=.053)$ and 7 $(\operatorname{Exp}(B)=1.50, p=.082)$. We proceeded to examine the engagementapprenticeship link separately for girls and boys.

Did goal engagement predict apprenticeship attainment for girls? We conducted a series of hierarchical logistic regression analyses predicting apprenticeship attainment for girls. In the first step, parental education and school achievement were entered in the model. School achievement predicted apprenticeship attainment $(\operatorname{Exp}(B)=1.37, p<.05)$ whereas parental education did not $(\operatorname{Exp}(B)=.89, p=.435)$. In the second step (see Table 3), goal engagement was included and emerged as a powerful predictor of apprenticeship attainment (wave 4: $\operatorname{Exp}(B)=1.92, p<.001$; wave 5: $\operatorname{Exp}(B)=1.45, p<.05$; wave $6: \operatorname{Exp}(B)=1.66, p<.01$; wave 7 : $\operatorname{Exp}(B)=1.41, p<.05)$. The school achievement effect was still positive but became nonsignificant.

Did the goal engagement effect become stronger across time for girls? We tested the equality of goal engagement coefficients at waves $4,5,6$, and 7 on apprenticeship attainment. Specifically, we compared a model with all variables entered simultaneously and coefficients constrained to be equal against a nonrestrictive model, controlling for

TABLE 3

Predicting Apprenticeship Attainment After Graduation for Girls

\begin{tabular}{lcccc}
\hline & Wave 4 & Wave 5 & Wave 6 & Wave 7 \\
\hline School achievement & 1.27 & 1.29 & 1.28 & 1.28 \\
Parental education & .93 & .92 & .93 & .93 \\
Goal engagement & $1.92^{* * * * *}$ & $1.45^{*}$ & $1.66^{* * *}$ & $1.41^{*}$ \\
Nagelkerke's $R^{2}$ & .15 & .08 & .10 & .07 \\
\hline
\end{tabular}

Note. Odds ratios $(\operatorname{Exp}(B))$ shown.

$* p<.05 ; * * p<.01 ; * * * * k<.001$. 
TABLE 4

Predicting Apprenticeship Attainment After Graduation for Boys

\begin{tabular}{lcccr}
\hline & Wave 4 & Wave 5 & Wave 6 & Wave 7 \\
\hline School achievement & 1.31 & 1.36 & 1.31 & 1.33 \\
Parental education & 1.03 & 1.02 & 1.04 & 1.03 \\
Goal engagement & 1.05 & .90 & 1.07 & .98 \\
Nagelkerke's $R^{2}$ & .02 & .02 & .02 & .02 \\
\hline
\end{tabular}

Note. Odds ratios $(\operatorname{Exp}(B))$ shown.

school achievement and parental education. We found that the effect of goal engagement on apprenticeship attainment differed across time $(F[4]=4.83, p<.01)$. However, contrary to our hypothesis, goal engagement at wave 4 , that is, early in the goal-striving process, emerged as the strongest predictor of apprenticeship attainment $(90 \%$ $\mathrm{CI}=1.45-2.53)$.

Did goal engagement predict apprenticeship attainment for boys? We then investigated apprenticeship attainment among boys using hierarchical logistic regression analyses. Again, we entered school achievement $(\operatorname{Exp}(B)=1.33, p=.159)$ and parental education $(\operatorname{Exp}(B)=$ $1.03, p=.868)$ in the first step. In the second step, goal engagement was included in the model (see Table 4). Goal engagement did not predict apprenticeship attainment (wave 4: $\operatorname{Exp}(B)=1.05, p=.794$; wave 5: $\operatorname{Exp}(B)=.90, p=.569 ; \quad$ wave $6: \operatorname{Exp}(B)=1.07, p=.696 ;$ wave 7 : $\operatorname{Exp}(B)=.98, p=.910)$. We tested the equality of goal engagement coefficients at waves $4,5,6$, and 7 on apprenticeship attainment using the procedure described above. Goal engagement effect sizes did not differ across time $(F[4]=.38, p=.821)$.

Figure 2 shows apprenticeship attainment chances for boys and girls. Whereas only $40 \%$ of girls with low goal engagement (below the median) attained an apprenticeship, their chances to attain an apprenticeship increased to $65.7 \%$ when they were highly engaged (above the median). In contrast, boys' apprenticeship attainment chances were $67.5 \%$ at low and $72.6 \%$ at high levels of goal engagement.

\section{Goal Engagement and Positive Affect}

In the final set of analyses, we analyzed longitudinal relations between goal engagement and positive affect. We controlled our analyses for base- 


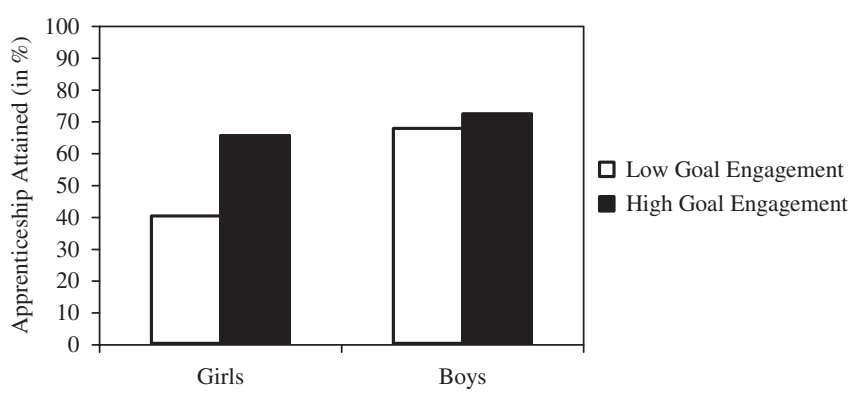

FIGURE 2 Goal engagement before and apprenticeship attainment after graduation for boys and girls.

Note. Goal engagement measured at wave 4 .

line positive affect. First, we tested whether goal engagement before graduation predicted positive affect after graduation. As we postulated apprenticeship attainment to mediate the goal engagement-affect link, we controlled the following analyses for the main and interaction effects of school achievement, parental education, and gender. Second, we investigated whether the goal engagement effect became stronger across time. Finally, we investigated whether apprenticeship attainment mediated the effect of goal engagement on positive affect.

\section{Did goal engagement before predict positive affect after} graduation? Results from the hierarchical linear regression analyses predicting positive affect after graduation by goal engagement measured at wave 4 are shown in Table 5. Goal engagement predicted positive affect after graduation $(\beta=.20, p<.001)$, controlling for positive affect at wave $4(\beta=.28$, $p<.001)$, school achievement, parental education $(\beta=.13, p<.05)$, and gender. No interaction effects between goal engagement and the structural variables were found. Thus, the overall effect of goal engagement on positive affect did not differ across school achievement (interaction: $\beta=-.09, p=.826$ ), parental education (interaction: $\beta=-.04, p=.918$ ), and, notably, gender (interaction: $\beta=.06, p=.864)$.

The overall regression pattern remained stable across time. Goal engagement predicted positive affect after graduation at wave $5(\beta=.16$, $p<.01)$, wave $6(\beta=.19, p<.001)$, and wave $7(\beta=.17, p<.01)$, controlling for school achievement, parental education, gender, and baseline positive affect measured at waves 5,6 , and 7 , respectively. Parental education (wave $5: \beta=.11, p<.05$; wave $6: \beta=.09, p=.067$; wave $7: \beta=.09, p=.057$ ) and baseline positive affect (wave $5: \beta=.36, p<.001$; wave $6: \beta=.42$, $p<.001$; wave $7: \beta=.46, p=.001$ ) also emerged as predictors of positive affect after graduation. 
TABLE 5

Predicting Positive Affect After Graduation

\begin{tabular}{lcc}
\hline & Step 1 & Step 2 \\
\hline School achievement & .05 & .02 \\
Parental education & $.11^{*}$ & $.13^{*}$ \\
Gender & -.06 & -.08 \\
Positive affect baseline & $.34^{* * * * *}$ & $.28^{* * * *}$ \\
Goal engagement & & $.20^{* * * *}$ \\
$R^{2}$ & .14 & .18 \\
\hline
\end{tabular}

Note. Goal engagement and positive affect measured at wave 4. Standardized regression coefficients $(\beta)$ shown.

$* p<.05 ; * * * * p<.001$.

Did the goal engagement effect become stronger across time? We tested the equality of goal engagement regression coefficients following the procedure described above, controlling for school achievement, parental education, and gender. The goal engagement coefficients differed significantly across time $(F[4]=12.72, p<.001)$. This pattern remained stable when controlling for positive affect measured at wave 4 $(F[4]=7.66, p<.001)$. When controlling for baseline positive affect at all waves $(4,5,6$, and 7$)$ the goal engagement regression coefficients still differed from each other $(F[4]=3.30, p<.05)$. However, inspection of confidence intervals indicated that the coefficients did not differ significantly (wave 4: $B=.12,90 \% \mathrm{CI}=.07-.17$; wave $5: B=.09,90 \% \mathrm{CI}=.04-14$; wave $6: B=.11$, $90 \% \mathrm{CI}=.06-.16$; wave $7: B=.10,90 \% \mathrm{CI}=.05-.15)$.

Did apprenticeship attainment mediate the effect of goal engagement on positive affect? Finally, we investigated the mediating role of apprenticeship attainment in the goal engagement-affect link. Mediation analyses were conducted using the Sobel test (Sobel, 1982; see Baron \& Kenny, 1986). As we had found notable gender differences in the association between goal engagement and apprenticeship attainment, we conducted the following analyses separately for boys and girls.

Girls. First, we investigated whether apprenticeship attainment mediated the effect of goal engagement measured at wave 4 on positive affect after graduation. Goal engagement predicted apprenticeship attainment after graduation $(\operatorname{Exp}(B)=1.95, p<.001)$, but apprenticeship attainment did not 
predict positive affect after graduation, controlling for goal engagement $(\beta=.07, p=.349)$. Consequently, no mediation effect was found $(z=.91$, $p=.360$ ). This pattern remained stable across time. No mediation effect was found on analyzing goal engagement at wave $5(z=1.10, p=.272)$, wave 6 $(z=.95, p=.342)$, and wave $7(z=1.06, p=.290)$. Note that we controlled all our analyses for positive affect measured at waves $4,5,6$, and 7 , respectively.

Boys. Goal engagement did not predict apprenticeship attainment (see above), which also did not function as a mediator at wave $4(z=.75$, $p=.454)$, wave $5(z=-.17, p=.862)$, wave $6(z=.67, p=.500)$, and wave 7 $(z=.12, p=.905)$.

\section{DISCUSSION}

The present longitudinal study investigated engagement with an on-time developmental goal, attaining a desired career outcome, during the transition from school to work. Converging with predictions by the actionphase model of developmental regulation (Heckhausen, 1999), we showed that goal engagement was important for career goal attainment (i.e., apprenticeship) and well-being when goal attainment opportunities were constrained as was the case for girls in our study. When opportunities were better, as was the case for boys, goal engagement was not essential for attaining an apprenticeship, but proved beneficial for well-being.

\section{Goal Engagement and Career Goal Attainment}

Previous studies have demonstrated positive effects of individual goals and motivation during work-related life-span transitions on job attainment (e.g., Kanfer et al., 2001; Nurmi et al., 2002; Pinquart et al., 2003; Wiese et al., 2002). The present study focused on goal engagement and revealed that career-related goal engagement before graduation was important for girls' career goal (i.e., apprenticeship) attainment after graduation. Girls generally had lower chances to attain an apprenticeship, consistent with previous findings (e.g., Heinz, 2000). The German apprenticeship system amplifies gender inequality-which stems from many sources including employers' preferences, personnel practices, discrimination, and gendered career choice (e.g., Eccles, 1994; Reskin, 1993; Watt \& Eccles, 2008) — by offering only few female-typed positions (e.g., Heinz, 2000). We found that girls' chances to attain an apprenticeship improved markedly when they were highly goal-engaged, that is, when they invested effort and were volitionally focused on their career goal. In contrast, boys did not need high goal engagement in order to improve their apprenticeship chances, which already were quite high. 
School achievement and parental education did not moderate the goal engagement-apprenticeship link. These factors showed weak (school achievement) or no (parental education) main effects. Thus, they did not profoundly impact opportunities for apprenticeship attainment. Why were the effects not stronger as we had expected? Regarding school achievement, Heckhausen and Tomasik (2002) demonstrated impressive goal adjustment processes analyzing the same data set: Adolescents tailored the prestige of the apprenticeships they applied for to their school achievement. Regarding parental education, we suspect that no overall effect emerged because of the strong socioeconomic segregation of the German three-tiered school system (Schnabel et al., 2002). As demonstrated by Heinz, Kelle, Witzel, and Zinn (1998), the segregated school system mediates the influence of family background on school-to-work transition outcomes to a large extent.

\section{Goal Engagement and Positive Affect}

In the second set of analyses, we focused on positive affect as an important facet of subjective well-being (Lyubomirsky, King, \& Diener, 2005). Goal engagement before graduation predicted increases in positive affect after graduation in both boys and girls and hence proved beneficial for everyone. This finding converges with previous research (e.g., Määttä et al., 2002; Nurmi \& Salmela-Aro, 2002). We further found a small positive effect of parental education on positive affect after graduation. Goal engagement and positive affect were positively correlated concurrently, but only goal engagement predicted later apprenticeship attainment. Hence, positive affect by itself was not associated with later success in contrast to the findings reported by Lyubomirsky et al. (2005).

Whereas a number of studies on the action-phase model provide converging evidence on the adaptiveness of phase-congruent goal engagement for subjective well-being (e.g., Heckhausen et al., 2001), not much is known about what mediates this effect. Against our expectations, apprenticeship attainment did not mediate the link between goal engagement and positive affect. Post-hoc analyses revealed that apprenticeship attainment also did not moderate the engagement-affect link (for a contrasting finding, see Salmela-Aro \& Nurmi, 1997). ${ }^{1}$ One might further speculate that the expected mediational chain would emerge for negative

\footnotetext{
${ }^{1}$ Apprenticeship attainment did not moderate the effect of goal engagement on positive affect controlling for school achievement, parental education, and gender. After adding the interaction term, explained variance did not improve (wave 4: $\Delta R^{2}=.00$, wave $5: \Delta R^{2}=.00$, wave $6: \Delta R^{2}=.00$, wave $7: \Delta R^{2}=.01$ ) and goal engagement effects remained stable.
} 
affect, but post-hoc analyses indicated that pregraduation goal engagement had no effect on negative affect after graduation. ${ }^{2}$

The present findings indicate that-in the short run-goal engagement with a highly normative developmental goal (Heckhausen \& Tomasik, 2002) fosters positive affect even when this goal is not attained, perhaps because such goal engagement is socially supported and rewarded (Berger, Grob, \& Flammer, 1999; Flammer \& Avramakis, 1992). Follow-up analyses may elucidate the fate of those adolescents who remain highly engaged but do not manage to enter the apprenticeship system, which is an unfortunate reality for a considerable share of adolescents (Blossfeld, 1990). We would expect a breakdown of positive affect when goal engagement is continued unsuccessfully over a longer period of time (see Lucas, Clark, Georgellis, \& Diener, 2004).

\section{Goal Engagement When Approaching a Deadline}

Finally, we expected goal engagement to become more important in situations with lower goal attainment chances created not only by structural constraints but also by the developmental deadline of school graduation. Our study did not provide support for a stronger effect of goal engagement on post-transition affect with close deadline proximity. Contradicting the urgency hypothesis, the effect of goal engagement on apprenticeship attainment was strongest early in the goal striving phase. One might speculate that businesses and firms offer apprenticeship positions at the end of the school year, thus objectively creating more opportunities for apprenticeship attainment with increasing urgency. Clearly, further research is needed to test this idea.

\section{Limitations}

A number of limitations of our study have to be noted. First, considerable attrition occurred after graduation. Studies on life-span transitions often suffer from attrition, as participants-especially when young-are geographically mobile during such transitions. Nonetheless, we did not detect any systematic differences between those who left the sample and

\footnotetext{
${ }^{2}$ Career goal engagement did not predict negative affect after graduation controlling for school achievement, parental education, gender, and baseline negative affect at the respective waves (wave $4: \beta=-.07, p=.194$; wave $5: \beta=-.09, p=.075$; wave $7: \beta=-.06, p=.244$ ), with one exception (wave 6: $\beta=-.13, p<.01$ ). The latter effect disappeared when controlling for interactions between goal engagement and covariates.
} 
those who were retained in terms of any of the study variables, suggesting that attrition did not compromise the generalizability of our findings. Second, the study relied on adolescent self-report, which might have resulted in an overestimation of associations between variables. Third, the study used a longitudinal correlational design, which does not allow for causal inferences. When we speak of "effects" of goal engagement, we refer to temporal precedence, not to causal relations. Nonetheless, we think that our work provides interesting insights and suggests avenues for future research.

\section{Goal Engagement Under Structural and Temporal Constraints}

Converging with previous empirical studies and other models of developmental regulation, our study demonstrates the adaptiveness of on-time (e.g., Heckhausen et al., 2001; Wrosch \& Heckhausen, 1999; Wrosch et al., 2000) goal engagement (e.g., Baltes \& Baltes, 1990; Brandtstädter \& Rothermund, 2002; Riediger \& Freund, 2006) in terms of well-being. Our findings further show that goal engagement is particularly important for objective transition success in those adolescents who lack opportunities and receive little societal support and scaffolding.

In our study, girls were indeed able to improve their goal attainment chances when they were highly goal engaged. This finding documents how individual goal engagement can compensate for structural disadvantages. This may well hold not only for girls in Germany but also for particularly challenged groups among the "forgotten half" in the United States (Chang, Chen, Greenberger, Dooley, \& Heckhausen, 2006) or other countries, including ethnic minorities, inner-city youth, or youth with disabilities (see Osgood, Foster, Flanagan, \& Ruth, 2005). In the German context, we would expect goal engagement to be particularly important in the few middle-tier students who move on to higher education after graduation. Our finding that individual agency matters most when societal support is weak might also extend beyond the developmental context of the school-to-work transition to other life-span transitions (Caspi \& Moffitt, 1993), nonnormative challenges (Wrosch \& Freund, 2001), and times of social change (Silbereisen et al., 2007).

We further deem it an important task for future research to examine how pronounced structural constraints have to be so that individual goal engagement makes a difference and at which point they become too strong and override agency effects. To be clear, if contexts offer no opportunities, individual attempts to change the situation are doomed to fail. In this case, 
we would expect continued goal engagement to be maladaptive (Wrosch, Scheier, Carver, \& Schulz, 2003).

Future studies on goal engagement should expand the range of developmental outcomes by considering other career outcomes (e.g., apprenticeship attractiveness, work satisfaction), other well-being indicators (e.g., eudaimonic well-being) as well as adaptation in other developmental domains (e.g., peer and romantic relations, civic engagement). Finally, little is known about antecedents of on-time goal engagement. For example, how do parents, peers, or the broader social network (Jodl, Michael, Malanchuk, Eccles, \& Sameroff, 2001; Jokisaari \& Nurmi, 2005; Kracke, 2002) affect goal engagement? What personal resources (e.g., self-efficacy; Bandura, Barbaranelli, Caprara, \& Pastorelli, 2001) foster goal engagement? An investigation into antecedents of goal engagement will also be crucial for future interventions.

\section{Implications for Intervention}

In contemporary societies, work plays a central role in the lives of many individuals (e.g., Blustein, 1999). A successful entry into work is important, but has become increasingly challenging due to processes of social change (Mortimer \& Larson, 2002; Pinquart \& Silbereisen, 2005). It is a promising task to implement and evaluate theory-based prevention and intervention programs in order to help adolescents develop the goal engagement skills they need for a successful transition (see for example Solberg, Howard, Blustein, \& Close, 2002). Our findings suggest that goal engagement helps everyone to feel good. However, intervention programs may be needed most by disadvantaged populations for whom goal engagement is particularly important in order to avoid exclusion from the labor market.

\section{ACKNOWLEDGMENTS}

We would like to thank the three anonymous reviewers and Rainer K. Silbereisen, Michael Poulin, and Johann Jacoby for their most insightful comments on an earlier draft of this paper. We are indebted to the other members of the project team, Bettina Hollube, Gabriel Nagy, Nicole Radzei, Martin Tomasik, and Regina Wolf, for their manifold contributions to the project.

Analyses presented in this paper are based on data from a project on Developmental Regulation in the Transition from School to Vocational Education or Higher Education conducted at the Max Planck Institute for Human 
Development, Berlin, Germany. The study was funded by the German Research Foundation (He 3068/3-1). Collaborative work on this paper was supported by a grant from the German National Academic Foundation received by the first author and the Max-Planck-Award for International Cooperation funded by the German Federal Ministry of Education and Research (BMBF), which was received by the second author.

\section{APPENDIX}

\section{Goal Engagement}

I am ready to do everything necessary in order to get a suitable apprenticeship.

I invest all my energy in order to get a suitable apprenticeship.

I invest all my energy in order to have a good occupational future.

In order to follow a successful career path I invest effort wherever I can. While searching for an apprenticeship, I take care that other things do not distract me from my goal.

I take care that other things do not distract me from my goal of good occupational perspectives.

While searching for a suitable apprenticeship, I keep saying to myself that I will surely be successful.

When I am thinking about my career I keep saying to myself that I will surely be successful.

\section{REFERENCES}

Austin, J. T., \& Vancouver, J. B. (1996). Goal constructs in psychology: Structure, process, and content. Psychological Bulletin, 120, 338-375.

Baltes, P. B., \& Baltes, M. M. (1990). Psychological perspectives on successful aging: The model of selective optimization with compensation. In P. B. Baltes \& M. M. Baltes (Eds.), Successful aging: Perspectives from the behavioral sciences (pp. 1-34). New York: Cambridge University Press.

Bandura, A., Barbaranelli, C., Caprara, G. V., \& Pastorelli, C. (2001). Self-efficacy beliefs as shapers of children's aspirations and career trajectories. Child Development, 72, 187-206.

Baron, R. M., \& Kenny, D. A. (1986). The moderator-mediator variable distinction in social psychological research: Conceptual, strategic, and statistical considerations. Journal of Personality and Social Psychology, 51, 1173-1182.

Beck, U. (1986). Risikogesellschaft. Auf dem Weg in eine andere Moderne [Risk society. Towards a new modernity]. Frankfurt, Germany: Suhrkamp.

Berger, R. P., Grob, A., \& Flammer, A. (1999). Gender-role orientation and social expectations regarding female adolescents' coping with developmental tasks. Swiss Journal of Psychology, 58, 273-286. 
Blossfeld, H. -P. (1990). Changing educational careers in the Federal Republic of Germany. Sociology of Education, 63, 165-177.

Blossfeld, H. -P., Klijzing, E., Mills, M., \& Kurz, K. (Eds.). (2005). Globalization, uncertainty, and youth in society. The losers in a globalizing world. New York: Routledge.

Blustein, D. L. (1999). A match made in heaven? Career development theories and the schoolto-work transition. Career Development Quarterly, 47, 348-352.

Bourdieu, P. (2001). Masculine domination. Stanford, CA: Stanford University Press.

Bourdieu, P., \& Passeron, J. -C. (1990). Reproduction in education, society, and culture (2nd ed.). Thousand Oaks, CA: Sage.

Brandtstädter, J., \& Rothermund, K. (2002). The life-course dynamics of goal pursuit and goal adjustment: A two-process framework. Developmental Review, 22, 117-150.

Bronfenbrenner, U. (1979). The ecology of human development: Experiments by nature and design. Cambridge, MA: Harvard University Press.

Bühler, C. (1933). Der menschliche Lebenslauf als psychologisches Problem [The human life course as a psychological problem]. Leipzig: Hirzel.

Bynner, J. (1998). Education and family components of identity in the transition from school to work. International Journal of Behavioral Development, 22, 29-53.

Caspi, A., \& Moffitt, T. E. (1993). When do individual differences matter? A paradoxical theory of personality coherence. Psychological Inquiry, 4, 247-271.

Chang, E. S., Chen, C., Greenberger, E., Dooley, D., \& Heckhausen, J. (2006). What do they want in life? The life goals of a multi-ethnic, multi-generational sample of high school seniors. Journal of Youth and Adolescence, 35, 321-332.

Christmas-Best, V. E., \& Schmitt-Rodermund, E. (2001). Adolescents' career choices in East and West Germany after reunification: Interregional and intraregional differences and the role of gender. American Behavioral Scientist, 44, 1879-1898.

Cohen, J., Cohen, P., West, S. G., \& Aiken, L. S. (2003). Applied multiple regression/correlation analysis for the behavioral sciences (3rd ed.). Mahwah, NJ: Erlbaum.

Clausen, J. S. (1991). Adolescent competence and the shaping of the life course. American Journal of Sociology, 96, 805-842.

Diener, E., Lucas, R. E., \& Scollon, C. N. (2006). Beyond the hedonic treadmill. Revising the adaptation theory of well-being. American Psychologist, 61, 305-314.

Dietrich, H. (2004). Der große JUMP auf dem Arbeitsmarkt. Fördermaßnahmen für Jugendlichen und ihre Grenzen [The big JUMP on the labor market. Policy measures for adolescents and their limits]. Jugendnachrichten, 5, 7-8.

Dooley, D., \& Prause, J. (2004). The social costs of underemployment: Inadequate employment as disguised unemployment. New York: Cambridge University Press.

Eccles, J. S. (1994). Understanding women's educational and occupational choices: Applying the Eccles et al. model of achievement-related choices. Psychology of Women Quarterly, 18, 585-609.

Eccles, J. S., \& Wigfield, A. (2002). Motivational beliefs, values, and goals. Annual Review of Psychology, 53, 109-132.

Elder, G. H., Jr. (1998). The life course as developmental theory. Child Development, 69, 1-12.

Emirbayer, M., \& Mische, A. (1998). What is agency? American Journal of Sociology, 103, 9621023.

Emmons, R. A. (1986). Personal strivings: An approach to personality and subjective wellbeing. Journal of Personality and Social Psychology, 51, 1058-1068.

Evans, K. (2007). Concepts of bounded agency in education, work, and the personal lives of young adults. International Journal of Psychology, 42, 85-93. 
Flammer, A., \& Avramakis, J. (1992). Developmental tasks: Where do they come from? In M. von Cranach, W. Doise, \& G. Mugny (Eds.), Social representations and the social bases of knowledge (pp. 56-63). Ashland, OH: Hogrefe/Huber.

Gaskell, J. S. (1992). Gender matters from school to work. Milton Keynes, UK: Open University Press.

Granato, M., \& Schittenhelm, K. (2004). Junge Frauen. Bessere Schulabschlüsse-aber weniger Chancen beim Übergang in die Berufsausbildung [Young females: Better grades-but lower chances during the school-to-work transition]. Aus Politik und Zeitgeschichte, 28, 31-39.

Halpern, S. (1998). The forgotten half revisited: American youth and young families, 1988-2008. Washington, DC: American Youth Policy Forum.

Hamilton, S. F. (1990). Apprenticeship for adulthood: Preparing youth for the future. New York: Free Press.

Hamilton, S. F., \& Lempert, W. (1996). The impact of apprenticeship on youth: A prospective analysis. Journal of Research on Adolescence, 6, 427-455.

Havighurst, R. J. (1976). Developmental tasks and education (3rd ed.). New York: David McKay.

Heckhausen, J. (1999). Developmental regulation in adulthood: Age-normative and sociostructural constraints as adaptive challenges. New York: Cambridge University Press.

Heckhausen, J. (2002). Transition from school to work: Societal opportunities and the potential for individual agency. Journal of Vocational Behavior, 60, 173-177.

Heckhausen, J., \& Heckhausen, H. (2006). Motivation und Handeln [Motivation and action]. (3rd ed.). Heidelberg, Germany: Springer.

Heckhausen, J., \& Schulz, R. (1995). A life-span theory of control. Psychological Review, 102, 284-304.

Heckhausen, J., \& Schulz, R. (1999). Selectivity in life-span development: Biological and societal canalizations and individuals' developmental goals. In J. Brandtstädter \& R. M. Lerner (Eds.), Action and self-development: Theory and research through the life span (pp. 67103). Thousand Oaks, CA: Sage.

Heckhausen, J., Schulz, R., \& Wrosch, C. (1998). Developmental regulation in adulthood: Optimization in primary and secondary control-A multiscale questionnaire (Tech. Rep.). Berlin, Germany: Max Planck Institute for Human Development.

Heckhausen, J., \& Tomasik, M. J. (2002). Get an apprenticeship before school is out: How German adolescents adjust vocational aspirations when getting close to a developmental deadline. Journal of Vocational Behavior, 60, 199-219.

Heckhausen, J., Wrosch, C., \& Fleeson, W. (2001). Developmental regulation before and after a developmental deadline: The sample case of "biological clock" for childbearing. Psychology and Aging, 16, 400-413.

Heinz, W. R. (2000). Youth transitions and employment in Germany. International Social Science Journal, 164, 161-170.

Heinz, W. R. (2002). Transition discontinuities and the biographical shaping of early work careers. Journal of Vocational Behavior, 60, 220-240.

Heinz, W. R. (2008). Ausbildung, Arbeit, und Beruf [Education, work, and vocation]. In R. K. Silbereisen \& M. Hasselhorn (Eds.) Enzyklopädie Psychologie, Vol. 5. Entwicklungspsychologie des Jugendalters (pp. 255-290). Göttingen, Germany: Hogrefe.

Heinz, W. R., Kelle, U., Witzel, A., \& Zinn, J. (1998). Vocational training and career development in Germany: Results from a longitudinal study. International Journal of Behavioral Development, 22, 77-101.

Jodl, K. M., Michael, A., Malanchuk, O., Eccles, J. S., \& Sameroff, A. (2001). Parents' roles in shaping early adolescents' occupational aspirations. Child Development, 72, 1247-1265. 
Jokisaari, M., \& Nurmi, J. -E. (2005). Company matters: Goal-related social capital in the transition to working life. Journal of Vocational Behavior, 67, 413-428.

Jugendwerk der Deutschen Shell (Ed.). (1997). Jugend '97' [Youth 97]. Opladen, Germany: Leske+Budrich.

Kalakoski, V., \& Nurmi, J.-E. (1998). Identity and educational transitions: Age differences in adolescent exploration and commitment related to education, occupation, and family. Journal of Research on Adolescence, 8, 29-47.

Kanfer, R., Wanberg, C. R., \& Kantrowitz, T. M. (2001). Job search and employment: A personality-motivational analysis and meta-analytic review. Journal of Applied Psychology, 86, 837-855.

Kracke, B. (2002). The role of personality, parents, and peers in adolescents' career exploration. Journal of Adolescence, 25, 19-30.

Lazarus, R. S., \& Folkman, S. (1984). Stress, appraisal, and coping. New York: Springer.

Lehmann, W. (2004). 'For some reason I get a little scared': Structure, agency, and risk in school-work transitions. Journal of Youth Studies, 7, 379-396.

Lent, R. W., \& Worthington, R. L. (1999). Applying career development theories to the school-to-work transition process [Special issue]. Career Development Quarterly, 47, 291-296.

Lerner, R. M., \& Busch-Rossnagel, N. (Eds.). (1981). Individuals as producers of their development: A life-span perspective. New York: Academic Press.

Lerner, R. M., \& Walls, T. (1999). Revisiting individuals as producers of their development: From dynamic interactionism to developmental systems. In J. Brandtstädter \& R. M. Lerner (Eds.), Action and self-development: Theory and research through the life span (pp. 3-36). Thousand Oaks: Sage.

Lewin, K. (1926). Vorsatz, Wille und Bedürfnis [Intention, will, and need]. Psychologische Forschung, 7, 330-385.

Linnenbrink, E. A., \& Pintrich, P. R. (2002). Motivation as an enabler for academic success. School Psychology Review, 31, 313-327.

Little, B. R., Salmelo-Aro, K., \& Phillips, S. D. (Eds.). (2006). Personal projects pursuit: Goals, action, and human flourishing. Hillsdale, NJ: Lawrence Erlbaum.

Little, R. J. A., \& Rubin, D. B. (1987). Statistical analysis with missing data. New York: Wiley.

Lucas, R. E., Clark, A. E., Georgellis, Y., \& Diener, E. (2004). Unemployment alters the set point for life satisfaction. Psychological Science, 15, 8-13.

Lyubomirsky, S., King, L., \& Diener, E. (2005). The benefits of frequent positive affect: Does happiness lead to success? Psychological Bulletin, 131, 803-855.

Määttä, S., Nurmi, J. -E., \& Majava, E. -M. (2002). Young adults' achievement and attributional strategies in the transition from school to work: Antecedents and consequences. European Journal of Personality, 16, 295-312.

Mortimer, J. T., \& Larson, R. W. (Eds.). (2002). The changing adolescent experience: Societal trends and the transition to adulthood. New York: Cambridge University Press.

Nagy, G., Köller, O., \& Heckhausen, J. (2005). Der Übergang von der Schule in die berufliche Erstausbildung. Wer die Sorgen scheut, wird von ihnen ereilt [The transition from school to vocational education: Avoiding worry does not pay]. Zeitschrift für Entwicklungspsychologie und Pädagogische Psychologie, 37, 156-167.

Nurmi, J. -E., \& Salmela-Aro, K. (2002). Goal construction, reconstruction and depressive symptoms in a life-span context: The transition from school to work. Journal of Personality, $70,385-420$.

Nurmi, J. -E., \& Salmela-Aro, K. (2006). What works makes you happy: The role of personal goals in life-span development. In M. Csikszentmihalyi \& I. S. Csikszentmihalyi (Eds.), A 
life worth living: Contributions to positive psychology (pp. 182-199). New York: Oxford University Press.

Nurmi, J. -E., Salmela-Aro, K., \& Koivisto, P. (2002). Goal importance and related achievement beliefs and emotions during the transition from vocational school to work: Antecedents and consequences. Journal of Vocational Behavior, 60, 241-261.

Organization for Economic Co-operation and Development. (Ed.). (2003). OECD employment outlook 2003. Paris: Organization for Economic Co-operation and Development.

Osgood, D. W., Foster, E. M., Flanagan, C., \& Ruth, G. R. (Eds.). (2005). On your own without a net: The transition to adulthood for vulnerable populations. Chicago: University of Chicago Press.

Pinquart, M., Juang, L. P., \& Silbereisen, R. K. (2003). Self-efficacy and successful school-towork transition: A longitudinal study. Journal of Vocational Behavior, 63, 329-346.

Pinquart, M., \& Silbereisen, R. K. (2005). Understanding social change in conducting research on adolescence. Journal of Research on Adolescence, 15, 395-405.

Poulin, M., Haase, C. M., \& Heckhausen, J. (2005). Engagement and disengagement across the life span: An analysis of two-process models of developmental regulation. In W. Greve, K. Rothermund, \& D. Wentura (Eds.), The adaptive self: Personal continuity and intentional self-development (pp. 117-135). Göttingen/New York: Hogrefe.

Poulin, M., \& Heckhausen, J. (2007). Stressful events compromise control strivings during a major life transition. Motivation and Emotion, 31, 300-311.

Reitzle, M., \& Silbereisen, R. K. (2000). The timing of adolescents' school-to-work transition in the course of social change: The example of German unification. Swiss Journal of Psychology, 59, 240-255.

Reskin, B. (1993). Sex segregation in the workplace. Annual Review of Sociology, 19, 241-270.

Riediger, M., \& Freund, A. M. (2006). Focusing and restricting: Two aspects of motivational selectivity in adulthood. Psychology and Aging, 21, 173-185.

Rothbaum, F., Weisz, J. R., \& Snyder, S. S. (1982). Changing the world and changing the self: A two-process model of perceived control. Journal of Personality and Social Psychology, 42, 5-37.

Saks, A. M., \& Ashforth, B. E. (1999). Effects of individual differences and job search behaviors on the employment status of recent university graduates. Journal of Vocational Behavior, 54, 335-349.

Salmela-Aro, K., \& Nurmi, J.-E. (1997). Goal contents, well-being, and life context during transition to university: A longitudinal study. International Journal of Behavioral Development, 20, 471-491.

Salmela-Aro, K., Nurmi, J.-E., Saisto, T., \& Halmesmäki, E. (2001). Goal reconstruction and depressive symptoms during the transition to motherhood: Evidence from two cross-lagged longitudinal studies. Journal of Personality and Social Psychology, 81, $1144-1159$.

Schnabel, K. U., Alfed, C., Eccles, J. S., Köller, O., \& Baumert, J. (2002). Parental influence on students' educational choices in the United States and Germany: Different ramificationssame effect? Journal of Vocational Behavior, 60, 178-198.

Schoon, I., Bynner, J., Joshi, H., Parsons, S., Wiggins, R. D., \& Sacker, A. (2002). The influence of context, timing, and duration of risk experiences for the passage from childhood to midadulthood. Child Development, 73, 1486-1504.

Schulenberg, J. E., Bryant, A. L., \& O'Malley, P. M. (2004). Taking hold of some kind of life: How developmental tasks relate to trajectories of well-being during the transition to adulthood. Development and Psychopathology, 16, 1119-1140.

Schulenberg, J., Maggs, J. L., \& Hurrelmann, K. (1997). Negotiating developmental transitions during adolescence and young adulthood: Health risks and opportunities. In J. Schulen- 
berg, J. L. Maggs, \& K. Hurrelmann (Eds.), Health risks and developmental transitions during adolescence (pp. 1-19). New York: Cambridge University Press.

Schulz, R., \& Heckhausen, J. (1996). A life span model of successful aging. American Psychologist, 51, 702-714.

Senatsverwaltung für Gesundheit und Soziales (1990). Sozialstrukturatlas Berlin: Eine disaggregierte statistische Sozialraumanalyse [Social structure atlas Berlin: A disaggregated statistical analysis of social space]. Berlin, Germany: Author.

Sennett, R. (1998). The corrosion of character: The personal consequences of work in the new capitalism. New York: W.W. Norton.

Shanahan, M. J., Mortimer, J. T., \& Krüger, H. (2002). Adolescence and adult work in the twenty-first century. Journal of Research on Adolescence, 12, 99-120.

Shanahan, M. J., \& Porfeli, E. (2002). Integrating the life course and life-span: Formulating research questions with dual points of entry. Journal of Vocational Behavior, 61, 398-406.

Silbereisen, R. K., Best, H., \& Haase, C. M. (2007). Editorial: Agency and human development in times of social change. International Journal of Psychology, 42, 73-76.

Sobel, M. E. (1982). Asymptotic confidence intervals for indirect effects in structural equation models. Sociological Methodology, 13, 290-312.

Solberg, V. S., Howard, K. A., Blustein, D. L., \& Close, W. (2002). Career development in the schools: Connecting school-to-work life. Counseling Psychologist, 30, 705-725.

Vondracek, F. W., Lerner, R. M., \& Schulenberg, J. E. (1986). Career development: A life-span developmental approach. Hillsdale, NJ: Lawrence Erlbaum.

Vondracek, F. W., \& Porfeli, E. J. (2003). The world of work and careers. In G. R. Adams \& M. D. Berzonsky (Eds.), Blackwell handbook of adolescence (pp. 109-128). Malden, MA: Blackwell.

Wanberg, C. R., Glomb, T. M., Song, Z., \& Sorensen, S. (2005). Job-search persistence during unemployment: A 10-wave longitudinal study. Journal of Applied Psychology, 90, 411-430.

Watson, D., Clark, L. A., \& Tellegen, A. (1988). Development and validation of brief measures of positive and negative affect: The PANAS scales. Journal of Personality and Social Psychology, 54, 1063-1070.

Watt, H. M. G., \& Eccles, J. S. (Eds.). (2008). Gender and occupational outcomes: Longitudinal assessments of individual, social, and cultural influences. Washington, DC: American Psychological Association.

Wiese, B. S., Freund, A. M., \& Baltes, P. B. (2002). Subjective career success and emotional wellbeing: Longitudinal predictive power of selection, optimization, and compensation. Journal of Vocational Behavior, 60, 321-335.

Wrosch, C., \& Freund, A. (2001). Self-regulation of normative and non-normative developmental challenges. Human Development, 44, 264-283.

Wrosch, C., \& Heckhausen, J. (1999). Control processes before and after passing a developmental deadline: Activation and deactivation of intimate relationship goals. Journal of Personality and Social Psychology, 77, 415-427.

Wrosch, C., Heckhausen, J., \& Lachman, M. E. (2000). Primary and secondary control strategies for managing health and financial stress across adulthood. Psychology and Aging, 15, 387-399.

Wrosch, C., Scheier, M. F., Carver, C. S., \& Schulz, R. (2003). The importance of goal disengagement in adaptive self-regulation: When giving up is beneficial. Self and Identity, 2, 1-20. 